\title{
APLIKASI SPEKTROFOTOMETRI TERHADAP PENENTUAN KADAR BESI SECARA KUANTITAIF DALAM SAMPEL AIR
}

\section{APPLICATION OF SPECTROPHOTOMETRY IN DETERMINATION OF IRON LEVELS QUANTITATIVELY IN SAMPLE WATER}

\author{
Nevita Lexia dan Khoirul Ngibad* \\ Program Studi Teknologi Laboratorium Medik Fakultas Ilmu Kesehatan Universitas Maarif Hasyim Latif, Sidoarjo, \\ Indonesia \\ *Email: khoirul_ngibad@dosen.umaha.ac.id
}

Diterima: 31 Mei 2020. Disetujui: 12 Februari 2021. Dipublikasikan: 3 Maret 2021

\begin{abstract}
Abstrak: Spektrofotometri UV-Vis merupakan salah satu metode pengukuran kuantitatif dalam kimia analisis yang menggunakan panjang gelombang $380-780 \mathrm{~nm}$. Review ini bertujuan untuk mengkaji metode spektrofotometri dalam pengukuran kadar besi dan mengkaji aplikasi metode spektrofotometri untuk pengukuran kadar besi yang terdapat dalam beberapa jenis sampel air. Sumber data sekunder yang digunakan sebagai referensi dalam review artikel ini diperoleh dari artikel penelitian yang dipublikasikan di jurnal ilmiah nasional. Pencarian artikel penelitian melalui aplikasi google chrome dengan beberapa situs search engine, seperti www.google.com dan https://scholar.google.com. Hasil review ini menunjukkan bahwa metode spektrofotometri dalam pengukuran kadar besi dalam air dapat dilakukan menggunakan reagen fenantrolin yang membuat warna larutan uji menjadi merah jingga yang diukur absorbansinya pada panjang gelombang $510 \mathrm{~nm}$. Metode spektrofotometri dapat diaplikasikan untuk dalam pengukuran kadar besi dalam air sumur, air minum isi ulang, air gambut, dan air PDAM. Ambang batas maksimum besi dalam air minum sesuai dengan Peraturan menteri Kesehatan RI No. 32 Tahun 2017 adalah sebesar $1 \mathrm{mg} / \mathrm{L}$.
\end{abstract}

Kata Kunci: Spektrofotometri, Kadar besi, Air

\begin{abstract}
UV-Vis spectrophotometry is one of the quantitative measurement methods in chemical analysis that used wavelength of $380-780 \mathrm{~nm}$. This review aims to examine the spectrophotometric method for measuring iron content and examine the application of the spectrophotometric method for measuring iron content contained in several types of water samples. Secondary data sources used as references in this article review were obtained from research articles published in national scientific journals. Searching for research articles through the Google Chrome application with several search engine sites, such as www.google.com and https://scholar.google.com. The results of this review indicated that the spectrophotometric method for measuring iron content in water can be carried out using phenanthroline reagents which make the test solution color red orange which can be measured for absorbance at a wavelength of $510 \mathrm{~nm}$. Spectrophotometric methods can be applied to measure iron content in well water, refill drinking water, peat water, and PDAM water. The maximum limit of iron in drinking water is in accordance with the Minister of Health Regulation No. 32 of 2017 is $1 \mathrm{mg} / \mathrm{L}$.
\end{abstract}

Keywords: Spectrophotometry, Iron Content, Water

\section{PENDAHULUAN}

Air merupakan kebutuhan dasar yang penting untuk menunjang aktivitas manusia setiap harinya. Air digunakan oleh manusia untuk kebutuhan rumah tangga, industri, irigasi, minum dan lain-lain. Jenis air meliputi: air kolam renang, air minum, air pemandian dan air bersih [1]. Namun, tidak semua jenis air dapat dikonsumsi secara langsung karena adanya pencemaran air sehingga membahayakan kesehatan manusia. Pencemaran berbahaya salah satunya adalah pencemaran logam besi $(\mathrm{Fe})$. Logam besi $(\mathrm{Fe})$ adalah salah satu jenis zat polutan lingkungan yang biasanya ditemukan dalam perairan. Kandungan logam besi $(\mathrm{Fe})$ pada perairan secara ilmiah berada dengan jumlah yang lebih sedikit. Akan tetapi, dengan adanya aktifitas masyarakat disekitar perairan seperti industri, domestik, dan lainnya menjadikan faktor terjadinya peningkatan jumlah kandungan logam besi. Kandungan logam besi pada air berasal dari larutan batu-batuan yang mengandung senyawa Fe seperti Pyrit [2].

Kualitas air dapat dilihat dari 3 aspek, yaitu: aspek kimia, aspek fisika dan aspek biologi. Parameter wajib pada aspek fisika adalah kekeruhan, warna, zat padat terlarut, suhu, rasa dan bau. Untuk parameter kimia yang harus diperiksa adalah $\mathrm{pH}$, kadar besi, kadar fluorida, kesadahan, mangan, nitrit, nitrat, sianida, deterjen dan pestisida total. Parameter wajib untuk aspek biologi adalah total coliform dan E. coli [3].

Dalam penentuan kualitas air pada parameter kimia salah satunya adalah kadar besi. Standar kadar 
maksimum besi di dalam air minum sesuai dengan Peraturan menteri Kesehatan RI no. 32 tahun 2017 yaitu $1 \mathrm{mg} / \mathrm{L}$. Apabila kadar besi dikonsumsi melebihi batas maksimum yang telah ditetapkan Pemerintah dengan terus menerus dengan jangka waktu yang cukup lama, maka dapat mengakibatkan sirosis pada hati, hemochromatosis, diare, coma, irritability, dan sakit perut. Selain itu, Fe yang terakumulasi di dalam alveolus dapat mengakibatkan berkurangnya fungsi paru-paru sehingga menyebabkan kematian [4].

Kandungan besi dalam kandungan air tanah, umumnya berupa Fe (II) karena belum tercampur dengan oksigen dari atmosfer. Air tanah mempunyai konsentrasi karbondioksida $\left(\mathrm{CO}_{2}\right)$ yang tinggi mengakibatkan konsentrasi besi berupa mineral tidak dapat larut. Ion ferri $\left(\mathrm{Fe}^{3+}\right)$ tereduksi menjadi besi yang dapat larut dalam bentuk ion ferro $\left(\mathrm{Fe}^{2+}\right)$. Pada air tanah yang tidak mengandung $\mathrm{O}_{2}$, besi berperan sebagai ion ferro $\left(\mathrm{Fe}^{2+}\right)$ yang cukup tinggi sedangkan, pada air yang mengalir dan terjadi proses aerasi atau penambahan $\mathrm{O}_{2}$,ion ferro $\left(\mathrm{Fe}^{2+}\right)$ teroksidasi menjadi ferri oksihidroksida atau $\mathrm{Fe}(\mathrm{OH})_{3}$, dimana $\mathrm{Fe}(\mathrm{OH})_{3}$ ini lebih sulit larut dalam pH 6 sampai 8 [5].

Spektrofotometeri UV-Vis adalah salah satu teknis analisis spektroskopi dalam menggunakan sumber utama gelombang elektromagnetik dengan ultra violet (UV) untuk panjang gelombang (190-380 nm) dan sinar tampak (Visible) dengan panjang gelombang (380-780 nm). Spektrofotometeri UV-Vis biasanya digunakan sebagai analisa kuantitatif daripada analisisa kualitatif [5]. Metode spektrofotometeri UV-Vis telah digunakan untuk analisis kadar Fe [6], [4], ammonium [7], dan fosfat [8]. Untuk analisis kadar besi, Beberapa senyawa pengompleks yang dapat digunakan adalah molybdenum selenit, difenilkarbazon, fenantrolin dan Alizarin Red S (ASR) [9]. Dalam review artikel ini, akan dikaji terkait penerapan metode spektrofotometri dalam penentuan kadar besi (Fe) dalam beberapa jenis sampel air.

\section{METODE PENELITIAN}

Sumber data yang digunakan sebagai referensi dalam review artikel ini diperoleh dari internet, yaitu berupa artikel penelitian yang dipublikasikan di jurnal kompleks yang berwarna stabil dengan waktu yang cukup lama. Penambahan fenantrolin sebagai senyawa bidentat yang dapat menghasilkan kompleks dengan ion ferro $\left(\mathrm{Fe}^{2+}\right)$ yang berikatan secara kovalen sehingga menghasilkan warna merah-jingga. Reaksi pada besi (II) dengan fenantrolin adalah sebagai berikut:

$\mathrm{Fe}^{2+}+3 \mathrm{o}-$ phen $\longleftrightarrow\left[\mathrm{Fe}(\mathrm{o}-\text { phen })_{3}\right]^{2+}$ (merah jingga)

Fenantrolin dapat membentuk senyawa kompleks berwarna dengan Besi (III) atau ferri oksihidroksida, namum ketika fenantrolin bereaksi ilmiah nasional. Pencarian istilah yang dilakukan untuk memperoleh referensi jurnal ilmiah adalah menggunakan kata-kata atau fase kata yang berhubungan dengan "Penentuan kadar besi (Fe) dalam air menggunakan spektrofotometer UV-Vis", "Analisis kadar besi dalam sampel air menggunakan spektrofotometer UV-Vis", dan "Pengukuran konsentrasi $\mathrm{Fe}$ dalam air menggunakan spektrofotometer UV-Vis". Pencarian artikel penelitian melalui aplikasi google chrome dengan beberapa situs search engine, seperti www.google.com dan https://scholar.google.com. Kemudian, artikel-artikel yang sudah sesuai dengan kata kunci yang dikehendaki, maka artikel tersebut didownload lalu disimpan untuk dilakukan penyaringan untuk dijadikan referensi dalaam review artikel.

\section{HASIL DAN PEMBAHASAN}

Dalam bagian ini, dijelaskan tentang metode spektrofotometri dalam pengukuran kadar besi $(\mathrm{Fe})$ dan aplikasi metode spektrofotometri untuk pengukuran kadar besi yang terdapat dalam beberapa jenis sampel air. Pengukuran kadar besi metode spektrofotometri menggunakan bermacam - macam reagen dan terbentuk warna larutan uji yang kemudian ditentukan panjang gelombangnya berdasarkan warna larutan uji yang terbentuk.

\section{Metode Spektrofotometer dalam Pengukuran Kadar Besi}

Beberapa penelitian tentang analisis kadar Fe menggunakan spektrofotometeri dalam sampel perairan sudah banyak dilakukan. Tabel 1 . Menunjukkan penelitin-penelitian tentang penentuan kadar Fe menggunakan spektrofotometeri dari berbagai sampel air. Berdasarkan tabel tersebut dapat diketahui bahwa analisis kadar Fe mempunyai warna larutan uji berwarna merah-jingga dengan panjang gelombang $510 \mathrm{~nm}$.

Dari beberapa jenis reagen yang sering digunakan dalam penentuan kadar Fe pada sampel air yaitu menggunakan fenantrolin. Karena kompleks Besi (II) fenantrolin dapat membentuk senyawa

dengan Besi (II) kemudian warna yang dihasilkan oleh kompleks Besi (III) ialah tidak optimal. Oleh karena itu, reagen pereduksi dapat dicampurkan sebelum warna kompleks Besi (III) terbentuk [10].

Reagen lain yang digunakan sebagai senyawa pengompleks dalam dalam penentuan kadar Fe dalam sampel air adalah kalium tiosianida. Reaksi yang terjadi antara Fe dan kalium tiosianida adalah sebagai berikut: $3 \mathrm{KCNS}+\mathrm{FeCl}_{3} \longrightarrow \mathrm{Fe}(\mathrm{CNS})_{3}+3 \mathrm{KCl}$ (larutan
merah darah) 
Ion besi $\left(\mathrm{Fe}^{3+}\right)$ yang terdapat pada sampel air akan beraksi dengan ion tiosianida $\left(\mathrm{CNS}^{-}\right)$kemudian membentuk senyawa kompleks besi (III) tiosianat atau $\mathrm{Fe}(\mathrm{SCN})_{3}$ sehingga muncul warna merah jingga [6]. Dalam review artikel analisis kadar besi ini, ditemukan banyak perbedaan dalam panjang gelombang dan reagen yang digunakan. Penentuan panjang gelombang ditentukan berdasarkan warna yang timbul setelah pencampuran larutan uji dengan reagen.

Tabel 1. Penelitian tentang analisis kadar Fe dari berbagai sampel air

\begin{tabular}{|c|c|c|c|c|c|c|c|c|}
\hline No. & Sampel & Reagen & $\begin{array}{c}\text { Warna } \\
\text { larutan uji }\end{array}$ & $\begin{array}{c}\text { Panjang } \\
\text { gelombang } \\
(\mathbf{n m})\end{array}$ & $\begin{array}{l}\text { Rentang } \\
\text { larutan } \\
\text { standar } \\
(\mathrm{mg} / \mathrm{L}) \\
\end{array}$ & $\begin{array}{l}\text { Persamaan } \\
\text { garis linear }\end{array}$ & $\begin{array}{l}\text { Koefisien } \\
\text { korelasi } \\
\left(\mathbf{R}^{2}\right)\end{array}$ & Ref \\
\hline 1. & $\begin{array}{c}\text { Air } \\
\text { sumur }\end{array}$ & $\mathrm{HNO}_{3} 4 \mathrm{~N}, \mathrm{KSCN}$ & - & 480 & $0,01-1,0$ & $\begin{array}{l}y=0,8061 x \\
-0,0005\end{array}$ & 0,9986 & [4] \\
\hline 2. & $\begin{array}{l}\text { Air } \\
\text { minum } \\
\text { isi ulang }\end{array}$ & Reagen $\mathrm{Fe}$ & - & - & - & - & - & [5] \\
\hline 3. & $\begin{array}{c}\text { Air } \\
\text { gambut }\end{array}$ & $\begin{array}{c}\mathrm{HCl}, \\
\text { hidroksilamain } \\
\text { hidroklorida, 1,10- } \\
\text { fenantrolin, buffer } \\
\text { ammonium asetat } \\
\text { pH } 4,5\end{array}$ & $\begin{array}{l}\text { Merah- } \\
\text { jingga }\end{array}$ & 510 & $1-5$ & $\begin{array}{c}y=0,1083 x \\
-0,0031\end{array}$ & 0,9969 & [11] \\
\hline 4. & $\begin{array}{c}\text { Air } \\
\text { irigasi }\end{array}$ & $\begin{array}{c}\mathrm{HNO}_{3}, \mathrm{Na}_{2} \mathrm{SO}_{3} \\
\text { EDTA, buffer } \\
\text { asetat pH } 4,5\end{array}$ & Jingga & 509 & $1-5$ & $\begin{array}{l}y=0,1105 x \\
+0,0031\end{array}$ & 0,9951 & [12] \\
\hline 5. & $\begin{array}{l}\text { Air } \\
\text { sumur } \\
\text { dan } \\
\text { PDAM }\end{array}$ & $\begin{array}{c}\mathrm{HCl}, \mathrm{HNO}_{3}, \\
\text { larutan } \\
\text { hidroksilamin } \\
\text { 20\%, buffer } \\
\text { ammonium asetat } \\
\text { pH 4, fenantrolin } \\
0,1 \%, \\
\text { kalium tiosianida } 2 \\
\mathrm{~N}\end{array}$ & $\begin{array}{l}\text { Merah } \\
\text { darah }\end{array}$ & 510 & - & $\begin{array}{l}y=0,2124 x \\
+0,0445\end{array}$ & 0,9999 & [6] \\
\hline 6. & $\begin{array}{l}\text { Air } \\
\text { sumur }\end{array}$ & KSCN 2 M & - & - & - & $\begin{array}{l}y=0,1194 x \\
+0,0047\end{array}$ & 0,9972 & [13] \\
\hline 7 & $\begin{array}{c}\text { Air } \\
\text { sumur }\end{array}$ & $\begin{array}{c}\mathrm{HNO}_{3} 4 \mathrm{~N} \text { dan } \\
\mathrm{KCNS}_{2} \mathrm{M}\end{array}$ & - & $477 \mathrm{~nm}$ & - & - & - & [14] \\
\hline 8 & $\begin{array}{l}\text { Air } \\
\text { sumur } \\
\text { gali }\end{array}$ & $\begin{array}{c}\text { Hidroksilamin, } \\
\text { 1,10-phenantrolin } \\
0,1 \% \text {, buffer asetat }\end{array}$ & - & - & - & $\begin{array}{l}y=0,201 x \\
\quad+0,003\end{array}$ & - & [15] \\
\hline 9 & $\begin{array}{l}\text { Air } \\
\text { boiler }\end{array}$ & $\begin{array}{l}\text { Hidroksilamin, } \\
\text { buffer asetat, } 1,10- \\
\text { penantrolin }\end{array}$ & - & $510 \mathrm{~nm}$ & - & - & - & [16] \\
\hline 10 & $\begin{array}{c}\text { Air } \\
\text { selokan }\end{array}$ & $\begin{array}{l}\text { Hidroksilamin } \\
\text { asam klorida, } \\
\text { ammonium } \\
\text { aasetat, } 1,10- \\
\text { fenantrolin }\end{array}$ & - & $510 \mathrm{~nm}$ & $0-0,8$ & $\begin{array}{c}y=0,098 x \\
-0,000\end{array}$ & 0,999 & [17] \\
\hline 11 & $\begin{array}{c}\text { Air } \\
\text { limbah }\end{array}$ & $\begin{array}{c}\text { Hidroksilamin- } \\
\mathrm{HCl} 5 \%, \\
\mathrm{CH}_{3} \mathrm{COONa} 5 \%, \\
1,10 \text { fenantrolin } \\
\end{array}$ & $\begin{array}{l}\text { Jingga- } \\
\text { merah }\end{array}$ & $510 \mathrm{~nm}$ & $1-3$ & $\begin{aligned} y & =0,195 x \\
& +0,051\end{aligned}$ & 0,9394 & [18] \\
\hline
\end{tabular}


Kinerja pengukuran menggunakan spektrofotometri dapat dilihat dari setidaknya 3 parameter, yaitu: 1) persamaan garis linear dengan nilai koefisien korelasi $\left(\mathrm{R}^{2}\right)$ yang mendekati angka 1 , 2) slope/gradien/kemiringan dengan nilai a yang paling besar, dan 3) linearitas dan rentang yang luas. Dalam review artikel di atas, penelitian yang menghasilkan $\mathrm{R}^{2}$ mendekati angka 1 adalah nomor 1 , 3, 4, 5, 6 dan 10 sedangkan penelitian yang menghasilkan nilai gradien terbesar adalah penelitian nomor 1. Di sisi lain, penelitian yang menghasilkan linearitas dan rentang yang luas adalah nomor 1 .

Berdasarkan Tabel 2, dapat diketahui bahwa pengukuran konsentrasi Fe bertujuan untuk mengetahui sampel air layak tidaknya dikonsumsi. Air layak konsumsi memiliki persyaratan yang khusus sehingga tidak dapat menimbulkan berbagai penyakit pada manusia. Standar konsentrasi maksimum besi di dalam air minum sesuai dengan Peraturan menteri Kesehatan RI no. 32 tahun 2017 yaitu $1 \mathrm{mg} / \mathrm{L}$.

Pada manusia, zat besi merupakan komponen penting yang terlibat dalam pengangkutan oksigen dan penting untuk pengaturan pertumbuhan sel. Kekurangan zat besi akan menyebabkan anemia. Di sisi lain, kelebihan zat besi dapat mengakibatkan keracunan dan bahkan kematian. Kelebihan zat besi dapat menyebabkan hemokromatosis idiopatik atau sebagai akibat dari kelebihan zat besi [19]. Hemokromatosis idiopatik adalah penyakit keturunan yang ditandai dengan kelebihan zat besi yang progresif akibat tingginya penyerapan zat besi di usus [20] .

Tabel 2. Hasil penentuan kadar besi dalam berbagai macam sampel air

\begin{tabular}{cccccc}
\hline No & Sampel & Konsentrasi $(\mathbf{m g} / \mathbf{L})$ & $\begin{array}{c}\text { Standar Baku } \\
\text { Mutu }(\mathbf{m g} / \mathbf{L})^{*}\end{array}$ & Kesimpulan & Ref \\
\hline 1. & Air sumur & $<0,3$ & 1 & Layak digunakan sehari-hari & {$[4]$} \\
2. & $\begin{array}{c}\text { Air minum } \\
\text { isi ulang }\end{array}$ & $0,03-0,08$ & 1 & Layak digunakan sehari-hari & {$[5]$} \\
3. & Air gambut & 3,387 & 1 & Tidak memenuhi syarat standar & {$[11]$} \\
5. & Air PDAM & $0,054-0,08$ & 1 & $\begin{array}{c}\text { Layak digunakan sehari-hari } \\
\text { Layak digunakan sehari-hari }\end{array}$ & {$[6]$} \\
6. & Air sumur & $0,114-0,439$ & 1 & [13]
\end{tabular}

*Permenkes No.32 Tahun 2017

\section{KESIMPULAN}

Metode spektrofotometri dalam pengukuran kadar besi dalam air dapat dilakukan menggunakan reagen fenantrolin yang membuat warna larutan uji menjadi merah jingga dan dapat diukur absorbansinya pada panjang gelombang $510 \mathrm{~nm}$. Metode spektrofotometri dapat diaplikasikan untuk dalam pengukuran kadar besi dalam air isi ulang, air minum, air sumur, dan air PDAM. Berdasarkan Peraturan Menteri Kesehatan Republik Indonesia nomor 32 tahun 2017, batas maksimum kadar besi $(\mathrm{Fe})$ pada sampel air adalah $1 \mathrm{mg} / \mathrm{L}$. Apabila kadar $(\mathrm{Fe})$ dikonsumsi dengan terus menerus pada jangka waktu yang panjang dapat mengakibatkan sirosis hati, hemochromatosis, diare, mual dan sakit perut.

\section{DAFTAR PUSTAKA}

[1] Ngibad, K., \& Herawati, D. (2019). Analisis Kadar Klorida Dalam Air Sumur Dan PDAM Di Desa Ngelom Sidoarjo. JKPK (Jurnal Kimia Dan Pendidikan Kimia), 1-9.

[2] Kamarati, K., Aipassa, M., \& Sumaryono, M. (2018). Kandungan Logam Berat Besi (Fe), Timbal (Pb) Dan Mangan (Mn) Pada Air Sungai Santan. Jurnal Penelitian Ekosistem Dipterokarpa, 4(1), 49-56.
[3] Permenkes, R. I. (2017). Standar Baku Mutu Kesehatan Lingkungan dan Persyaratan Kesehatan Air Untuk Keperluan Higiene Sanitasi, Kolam Renang, Solus per Aqua, dan Pemandian Umum.

[4] Andini, A. (2018). Analisa Kadar Fe (III) Air Di Kecamatan Tanggulangin Sidoarjo. Medical Technology and Public Health Journal, 2(1), 1924.

[5] Asmaningrum, H. P., \& Pasaribu, Y. P. (2016). Penentuan Kadar Besi (Fe) Dan Kesadahan Pada Air Minum Isi Ulang Di Distrik Merauke. Magistra: Jurnal Keguruan dan Ilmu Pendidikan, 3(2), 95-104.

6] Khaira, K. (2016). Penentuan Kadar Besi (Fe) Air Sumur dan Air PDAM Dengan Metode Spektrofotometri. Sainstek: Jurnal Sains Dan Teknologi, 5(1), 17-23.

[7] Ngibad, K. (2019). Penentuan Konsentrasi Ammonium dalam Air Sungai Pelayaran Ngelom. Medicra (Journal of Medical Laboratory Science/Technology), 2(1), 37-42.

[8] Ngibad, K. (2019). Analisis Kadar Fosfat Dalam Air Sungai Ngelom Kabupaten Sidoarjo Jawa Timur. Jurnal Pijar Mipa, 14(3), 197-201.

[9] Sari, N. (2015). Studi Gangguan Mg (II) Dalam Analisa Besi (II) Dengan Pengompleks 
Ofenantrolin Menggunakan Spektrofotometer UV-VIS (Doctoral dissertation, Institut Teknologi Sepuluh Nopember).

[10] Wang, S. (2016). Studi Gangguan $\mathrm{Cu}^{2+}$ pada Analisa Besi (III) dengan Pengompleks 1, 10Fenantrolin pada $\mathrm{pH} 3,5$ secara Spektrofotometri UV-Vis. Jurnal Sains dan Seni ITS, 4(2).

[11] Morti, T., Destiarti, L., \& Idiawati, N. (2018) Penentuan Kadar Besi (Fe) Pada Air Gambut Menggunakan Spektrofotometer Ultra VioletVisible Dengan Perbandingan Pengompleks Fenantrolin Dan Alizarin Red S. Jurnal Kimia Khatulistiwa, 7(3).

[12] Dianawati, N., \& R Djarot Sugiarso, K. S. (2016). Penentuan Kadar Besi Selama Fase Pematangan Padi Menggunakan Spektrofotometer UV-Vis. Jurnal Sains dan Seni ITS, 4(2).

[13] Sartikasari, M., Mulyono, T., \& Muflihah, Y. M. (2018). Analisis Ion $\mathrm{Fe}^{3+}$ dan Konduktivitas pada Air Sumur di Sekitar TPA Pakusari secara Simultan Menggunakan Metode Sequential Injection Analysis. BERKALA SAINSTEK, 6(1), 36-40.

[14] Pawarti, H., Citradewi, L. I., Fadhilla, A. T., \& Suhendi, A. (2019). Reduksi Kadar Besi Dalam Air Sumur di Lingkungan Universitas Muhammadiyah Surakarta dengan Filter. Pharmacon: Jurnal Farmasi Indonesia, 15(2), 52-57.

[15] Nicola, F. (2015). Hubungan Antara Konduktivitas, TDS (Total Dissolved Solid) dan TSS (Total Suspended Solid) dengan Kadar $\mathrm{Fe}^{2+}$ dan Fe Total Pada Air Sumur Gali.

[16] Laia, H. F. (2017). Penentuan Kadar Besi dari Air Boiler dengan Metode Spektrofotometri.

[17] Wulandari, T., \& Wahyuni, S. (2018). Analisis Kandungan Fe (II) Air Selokan di Sekitar TPA II Kelurahan Karya Jaya Musi 2 Palembang dengan Metode Spektrofotometri UV-Vis. ALKIMIA: Jurnal Ilmu Kimia dan Terapan ,15(2), 15-21.

[18] Solikha, D. F. (2018). Analisis Kadar Fe2+ dari suatu Sampel Limbah Laboratorium X di Kota Bandung Menggunakan Spektrofotometri Uvvis Jenis Spectronik-20. Syntax Literate; Jurnal Ilmiah Indonesia, 3(8), 13-26.

[19] Ahmed, M. J., \& Roy, U. K. (2009). A simple spectrophotometric method for the determination of iron (II) aqueous solutions. Turkish journal of chemistry, 33(5), 709-726.

[20] Marin, M. G. (1985). Idiopathic hemochromatosis. Minerva Med. 76(13), 627634. 